\title{
KERJASAMA ANTARA GURU PENDIDIKAN AGAMA ISLAM (PAI) DAN ORANG TUA DALAM MENINGKATKAN KEDISIPLINAN SHALAT SISWA KELAS V SDN 004 CISARANTEN KULON KECAMATAN ARCAMANIK KOTA BANDUNG
}

\author{
Dian, $\mathrm{N}^{1}$, Mulyasa, E, Fathurrohman, $\mathrm{A}^{2}$. \\ Universitas Islam Nusantara \\ ovidianmiftah73@gmail.com
}

\begin{abstract}
ABSTRAK
Latar belakang penelitian adalah Islam mengajarkan agar proses penanaman disiplin dalam pelaksanaan salat 5 waktu harus ditanamkan sejak dini.Kerja sama antara guru PAI dan orang tua siswa untuk mendidik pembiasaan salat 5 waktu kepada siswa, dilatarbelakangi oleh kegiatan pengisian buku penghubungan salat 5 waktu siswa. Kegiatan ini merupakan kerja sama antara guru PAI dan orang tua dalam upaya mereka untuk meningkatkan kedisiplinan salat 5 waktu siswa. Tujuan penelitian ini adalah untuk mengetahui deskripsi mengenai desain, pelaksanaan, keberhasilan, faktor pendukung dan penghambat pelaksanaan kerja sama antara guru PAI dan orang tua untuk meningkatkan kedisiplinan siswa dalam melaksanakan salat lima waktu. Metode penelitian yang di gunakan adalah metode kualitatif deskriptif, yaitu dengan memberikan gambaran secara faktual, dan akurat mengenai fakta-fakta yang berkaitan dengan desain, pelaksanaan kerja sama antara guru PAI dan orang tua siwa,keberhasilan serta faktor pendukung dan penghambat pelaksanaan kerja sama antara guru PAI dan orang tua untuk meningkatkan kedisiplinan siswa dalam melaksanakan salat lima waktu. Teknik pengumpulan data dalam penelitian ini melalui observasi,wawancara,dan dokumentasi. Hasil penelitian ini adalah diperoleh setelah dilaksanakannya desain program kedisiplinan salat melalui buku penghubung pada bulan Agustus dan September pada bulan September mengalami peningkatan siswa terlihat banyak melaksanakan salat di tempat-tempat ibadah. Hal ini menunjukkan bahwa pelaksanaan program sudah berhasil,teramati dengan banyaknya siswa yang melakukan salat fardu di mushala dan mesjid semakin bertambah. Guru PAI mampu melaksanakan program ini sesuai prosedur, seluruh pihak di sekolah mendukung adapun penghambat dari program ini dapat ditanggulangi dengan baik. Berdasarkan hasil penelitian ini disarankan prestasi anak dan disiplin salat dipertahankan dan ditingkatkan, agar memiliki kesadaran yang tinggi untuk memahami dan mengamalkan ajaran-ajaran agama Islam. Intensitas komunikasi dengan orang tua juga senantiasa dipertahankan bahkan ditingkatkan.
\end{abstract}

Kata Kunci : Kerja sama, Guru pendidikan Agama Islam, Orang Tua, Kedisiplinan Salat Siswa.

\section{ABSTRACT}

The research background is that Islam teaches that the process of instilling discipline in the implementation of the 5 daily prayers must be instilled from an early age. Collaboration between PAI teachers and parents of students to educate students about the habit of praying 5 times, is motivated by the activity of filling out the connecting book for the 5 daily prayers. This activity is a collaboration between Islamic Education teachers and parents in their efforts to improve the discipline of the students' 5 daily prayers. The purpose of this study was to determine a description of the design, implementation, success, supporting and inhibiting factors of the implementation of cooperation between Islamic Education teachers and parents to improve student discipline in carrying out the five daily prayers. The research method used is descriptive qualitative method, namely by providing a factual and accurate picture of the facts related to design, implementation of cooperation between Islamic education teachers

\footnotetext{
${ }^{1}$ Mahasiswa Pascasarjana UNINUS Bandung

${ }^{2}$ Dosen Pascasarjana UNINUS Bandung
} 
and parents of students, success and supporting and inhibiting factors for the implementation of cooperation between teachers. PAI and parents to improve student discipline in carrying out the five daily prayers. Data collection

techniques in this study through observation, interviews, and documentation.. This shows that the implementation of the program has been successful, it was observed that the number of students praying fardu in prayer rooms and mosques was increasing. PAI teachers are able to carry out this program according to the procedure, all parties in the school support it while the obstacles of this program can be overcome properly. Based on the results of this study, it is suggested that children's achievement and prayer discipline be maintained and improved, in order to have a high awareness of understanding and practicing the teachings of Islam. The intensity of communication with parents is also maintained and even improved.

Keywords $\quad$ : Cooperation, Teachers of Islamic Education, Parents, Discipline of Student Prayers 


\section{PENDAHULUAN}

Hubungan guru dengan siswa adalah hubungan fungsional, dalam arti pelaku pendidik dan pelaku terdidik, (Dimyati dan Mujiono, 2006:7). Hubungan yang terjalin karena fungsinya masing-masing, antara guru dan siswa saling bekaitan.

Keberadaan Pendidikan Agama Islam di sekolah umum semakin strategis dan mantaP, tetapi bukan berarti lepas dari masalah. Fakta yang ada justru muncul pada tataran implementasi. (Muhaimin dkk, 2012; 23-43)

Menurut Daulay (2012:68) Pelaksanaan pembelajaran pendidikan Agama Islam di sekolah umum seringkali muncul problematikaproblematika, diantaranya faktor yang mempengaruhi proses belajar mengajar adanya problematika: internal mencakup fisiologi dan psikologi dan eksternal, mencakup lingkungan dan instrumen. yaitu: lingkungan social dan instrument yang mencakup kurikulum, sarana dan prasarana.

Oleh karena itu untuk mengatasi permasalahan di atas, pada proses pembelajaran harus mencakup beberapa faktor, yang sangat berpengaruh dalam proses pendidikan anak di sekolah. Salah satunya adalah kerja sama yang proaktif antara guru dan orang tua, merupakan pendorong utama siswa dalam mengamalkan pelajaran-pelajaran yang mereka peroleh di sekolah, terutama pelajaran tentang ibadah dan tatakrama, termasuk dalam hal ini yaitu mengenai kedisiplinan siswa dalam melaksanakan salat lima waktu. Oleh karena itu, secara spesifik kerjasama yang harus dibangun antara guru Pendidikan Agama Islam dengan orang tua siswa.

Berdasarkan pengamatan awal dilakukan di kelas V SDN 004 Cisaranten Kulon Kecamatan Arcamanik Kota Bandung ternyata terdapat beberapa masalah berkenaan dengan kedisiplinan siswa dalam melaksanakan salat lima waktu. Kenyataan dilapangan menunjukkan kecenderungan-kecenderungan sebagai berikut: (1) materi dan praktek salat telah disampaikan dan diikuti dengan baik oleh siswa, (2) semua guru selalu menekankan dan mengingatkan pelaksanaan salat lima waktu kepada siswa, (3) semua sisiwa diwajibkan mengisi buku monitoring salat lima waktu, (4) semua guru memberi keleluasaan waktu bagi siswa pergi ke mesjid untuk melaksanakan salat pada jam istirahat. Namun semua upaya terebut belum cukup untuk membuat siswa untuk menjadi disiplin dalam melaksanakan salat lima waktu.

Latar belakang tersebut muncul disandingkan dengan suasana sekarang ini di tengah pandemic virus Covid 19 yang tengah mewabah, dimana pembalajaran dilaksanakan secara jarak jauh sehingga mau tidak mau orang tua harus terjun langsung untuk mendampingi putra putrinya dalam melaksanakan pembelajaran, maka dari itu penulis sangat tertarik untuk melaksanakan penelitian ini.

Berdasarkan hal tersebut, maka peneliti akan membahas dari beberapa aspek berikut:

1. Bagaimana desain peningkatan kedisiplinan siswa dalam melaksanakan salat lima waktu melalui kerjasama antara guru PAI dan orang tua di kelas V SDN 004 Cisaranten Kulon Kec. Arcamanik kota Bandung?

2. Bagaimana pelaksanaan kerjasama antara guru PAI dan orang tua untuk meningkatkan kedisiplinan siswa dalam melaksanakan salat lima waktu di kelas V SDN 004 Cisaranten Kulon Kec. Arcamanik kota Bandung?

3. Bagaimana keberhasilan pelaksanaan kerjasama antara guru PAI dan orang tua untuk melaksanakan kedisiplinan siswa dalam melaksanakan salat lima waktu di kelas V SDN 004 Cisaranten Kulon Kec. Arcamanik kota Bandung?

4. Apa saja faktor pendukung dan penghambat pelaksanaan kerjasama antara guru PAI dan orang tua untuk meningkatkan kedisiplinan siswa dalam melaksanakan salat lima waktu di kelas V SDN 004 Cisaranten Kulon Kec. Arcamanik kota Bandung.

\section{METODE PENELITIAN}

Penelitian ini dilaksanakan dengan menggunakan pendekatan kualitatif. Metode yang digunakan analisis deskriptif. Lokasi dan sumber data penelitian di SDN 004 Cisaranten Kulon Kec. Arcamanik kota Bandung. Teknik dan instrumen penelitian menggunakan observasi, wawancara dan dokumentasi. Sedangkan teknik analisis dilakukan melalui reduksi data,display data dan penarikan kesimpulan.Pengecekan keabsahan data menggunakan perpanjangan kehadiran, Trianggulasi peneliti tidak hanya mewawancarai satu orang guru tetapi mewawancarai tiga orang guru dan pemeriksaan teman sejawat.

Data Primer adalah data yang diperoleh secara langsung dari sumber informasi (informan) dalam hal ini yakni pengelola pembelajaran agama Islam di kelas V SDN 004 Cisaranten Kulon Kec. Arcamanik kota Bandung melalui penelitian di lapangan. Data primer akan diperoleh oleh peneliti melalui wawancara dengan beberapa responden, yaitu : 
1) Kepala SDN 004 Cisaranten Kulon Kec. Arcamanik kota Bandung,

2) Perwakilan komite sekolah SDN 004 Cisaranten Kulon Kec. Arcamanik kota Bandung 1 (satu) orang,

3) Perwakilan guru PAI SDN 004 Cisaranten Kulon Kec. Arcamanik kota Bandung 1 (satu) orang,

4) Perwakilan orang tua siswa kelas V SDN

004 Cisaranten Kulon Kec. Arcamanik kota Bandung 5 (lima) orang.

Data sekunder yang diperoleh peneliti merupakan data yang diperoleh langsung dari pihak-pihak yang berkaitan, misalnya terkait dengan profil sekolah, visi, misi, program-program pengembangan pengamalan keagamaan siswa, arsip-arsip, dokumen, dan lain sebagainya. Serta berbagai literatur yang relevan dengan pembahasan penelitian tentang "Kerjasama antara Guru Pendidikan Agama Islam dengan Orang Tua dalam meningkatkan kedisiplinan salat siswa".

\section{A. Kajian Teori}

Kerjasama adalah kegiatan atau usaha yang dilakukan oleh beberapa orang (lembaga, pemerintahan dan sebagainya) untuk mencapai tujuan bersama. Depdikbud, (2012:428). Dari penjelasan tersebut, maka pendekatan dan kerjasama yang harus terus menerus dikembangkan adalah pendekatan partisipatif, di mana masyarakat khususnya orang tua peserta didik dan pihak yang terkait diberi kesempatan yang seluas-luasnya untuk bersama-sama menganalisis seluruh infrastruktur yang ada di sekolah, apakah itu menyangkut Sumber Daya Manusia (SDM), kurikulum, sarana prasarana, finansial, sistem informasi, dan semua yang dianggap ada keterkaitan dengan sekolah tersebut.

Kerjasama tersebut terlebih dalam pelaksanaan pendidikan agama Islam terutama mengenai pendidikan keimanan dan ketaqwaan memang hanya sedikit sekali yang dapat dilakukan di sekolah. Padahal penanaman iman dan takwa itu adalah inti dari pendidikan agama islam. Sejalan dengan itu, Ahmad Tafsir menyatakan, orang tua harus menyelenggrakan pendidikan keimanan di rumah tangga. Dalam hal ini sekalipun guru berperan banyak, ia tidak mungkin mampu memainkan peran itu. Tafsir (2016:128). Kadangkadang orang tua terlambat menyadari perlunya kerjasama ini, maka pihak sekolah atau guru diharapkan mengambil inisiatif untuk menjalin kerjasama itu.

Dari penjelasan itu penulis berpendapat bahwa dengan terjalinnya kerjasama orang tua dan guru PAI secara baik dapat memudahkan hubungan yang harmonis antara keduanya, sehingga kegiatan pembelajaran baik dilaksanakan di sekolah maupun di rumah dapat berjalan dengan baik. Karena orang tua tidak mungkin memberikan pengetahuan sepenuhnya kepada anak-anaknya tanpa adanya guru, begitu pula sebaliknya guru tidak akan berhasil pembelajarannya tanpa adanya perhatian orang tua terhadap kegiatan belajar anaknya.

Keluarga atau orang tua adalah pondasi utama bagi pendidikan anak, dimana dia dibentuk oleh orang tua mereka. Orang tua merupakan guru pertama bagi anak dan segaligus sebagai panutan dan pembimbing dalam melewati fase-fase perkembangannya. Kebiasaan-kebiasaan di lingkungan keluarga sedikit banyak akan mempengaruhi kebiasaan anak-anak yang ada dalam lingkungan tersebut karena tipe kepribadian pada masa kanak-kanak adalah imitasi. Kian maraknya pelanggaran nialai moral oleh remaja dapat dipandang sebagai perwujudan rendahnya disiplin diri. Pemicu utamanya diduga adalah situasi dan kondisi keluarga yang negatif. (Shochib, 1998:V).

Peran keluarga terutama orang tua menjadi penting untuk mendidik anak baik tinjauan agama, sosial, maupun individu. Akan tetapi bagaimana pendidikan keluarga dapat berlangsung dengan baik sehingga mampu menumbuhkan perkembangan kepribadian anak menjadi manusia dewasa yang memiliki sikap positif terhadap agama, kepribadian yang kuat dan mandiri, potensi jasmani dan rohani serta intelektual yang berkembang secara optimal. Oleh karenaa itu, pendidikan dan pembinaan dalam keluarga merupakan kebutuhaan yang sangat mendasar dan penting.

Dalam keluarga, orang tua juga memegang peranan penting dalam memberikan keteladanan yang baik bagi anak. Sehingga orang tua sedini mungkin dapat mengenalkan nilai-nilai yang mengandung suasana religi. Syariat Islam membebani kewajiban orang tua untuk memelihara keselamatan anak dan perkembangan anak, atas dasar pertimbangan bahwa anak adalah titipan Allah SWT yang harus dijaga baik-baik sebab mereka akan mempertanggungjawabkan kepada Allah SWT. Firman Allah dalam surat At-Tahrim ayat 6 , yaitu:

Hai orang-orang yang beriman, peliharalah dirimu dan keluargamu dari api neraka yang bahan bakarnya adalah manusia dan batu; penjaganya malaikatmalaikat yang kasar, keras, dan tidak mendurhakai Allah terhadap apa yang 
diperintahkan-Nya kepada mereka dan selalu mengerjakan apa yang diperintahkan. Dhifier. (1986:29).

Di samping guru, orang tua merupakan model figur utama bagi anak, sebab orang tua memiliki peluang yang cukup banyak untuk mensosialisasikan aturan, nilai, dan kebiasaan serta sikap hidup. Disamping itu orang tua dalam keluarga juga merupakan sosok yang menjadi panutan dan perlakuan yang akan diterapkannya kepada anak-anaknya, serta mempunyai hak untuk mengasuh dan membesarkan anak-anaknya karena orang tua berperan sebagai guru, penuntun dan pengajar.

Menurut Sinungan,

(2002:146)

mengemukakan bahwa disiplin adalah sikap mental yang tercermin dalam perbuatan atau tingkah laku perorangan, kelompok atau masyarakat, yang berupa perkataan (obedience) terhadap peraturan yang ditetapkan atau etika, norma, dan kaidah yang berlaku dalam masyarakat untuk tujuan tertentu.

Sedangkan kedisiplinan menurut Fathoni, (2006:126) adalah kesadaran dan kesediaan seseorang menaati semua peraturan dan sadar akan tugas dan tanggungjawabnya. Kedisiplinan adalah kesadaran dan kesediaan seseorang dalam mentaati hukum, peraturan dan norma-norma yang berlaku. Seseorang dikatakan disiplin apabila orang tersebut bersedia memenuhi semua peraturan, serta melaksanakan tugas-tugasnya, baik secara sukarela atau terpaksa.

Jelaslah disini bahwa disiplin menghendaki ditaatinya peraturan-peraturan oleh para siswa sesuai dengan peraturan yang telah ditetapkan, dan sasarannya bukan pada hukuman tetapi pada perubahan tingkah laku. Sedangkan untuk merubah tingkah laku dan mengembangkan sikap disiplin tersebut diperlukan beberapa bentuk latihan. Dimana melalui latihan tersebut, orang tua diharapkan untuk berusaha menghargai waktu dengan melatih putri-putrinya untuk menaati waktu salat.

Penjelasan di atas dapat disimpulkan bahwa kerjasama yang baik antara guru PAI dan orang tua siswa akan meningkatkan kedisiplinan siswa dalam melaksanakan salat lima waktu. Kerjasama orang tua dan guru yang baik, dapat memudahkan hubungan yang harmonis antara keduanya, sehingga kegiatan pembelajaran baik dilaksanakan di sekolah maupun di rumah berjalan dengan baik. Karena orang tua tidak mungkin memberikan pengetahuan sepenuhnya kepada anak-anaknya tanpa adanya guru, begitu pula sebaliknya guru tidak berhasil pembelajaran tanpa adanya perhatian orang tua terhadap kegiatan belajar anaknya.

\section{B. Deskripsi Hasil Penelitian}

\section{Desain Peningkatan Kedisiplinan Siswa} dalam Melaksanakan Salat Lima Waktu Melalui Kerjasama Antara Guru PAI dan Orang Tua di Kelas V SDN 004 Cisaranten Kulon Kec. Arcamanik Kota Bandung

Desain peningkatan kedisiplinan siswa dalam melaksanakan salat lima waktu melalui kerja sama antara pihak sekolah atau guru PAI dan orang tua siswa di kelas V SDN 004 Cisaranten Kulon Kec. Arcamanik Kota Bandung yaitu, pertama dengan diadakannya program pertemuan antara pihak sekolah atau guru PAI dengan orang tua siswa secara rutin, maksimal waktu seminggu sekali atau minimal dalam jangka waktu tiga bulan sekali pertemuan dengan orang tua atau POM. Program pertemuan ini sudah tentu harus persetujuan kepala sekolah dengan kehadiran kepala sekolah lebih mendukung keberhasilan program kerja sama antara guru PAI dan orang tua dalam meningkatkan kedisiplinan salat siswa. Dengan adanya masa pandemi pertemuan dengan orang tua dilaksanakan melalui zoom meeting atau pertemuan langsung tetapi hanya melibatkan Perwakilan Orang Tua Murid (POM). Kedua, dengan menggunakan buku penghubung, yang dinamai "Buku Penghubung Laporan Pelaksanaan Salat Lima Waktu". Buku penghubung ini sabagai salah satu bentuk kerja sama antara sekolah dan orang tua siswa dalam meningkatkan ibadah salat siswa baik di rumah maupun di sekolah.

Orang tua/wali siswa di rumah diharuskan membantu melengkapi buku ini, dengan memperhatikan kedisiplinan salat siswa yang rutuin pelaksanaannya baik secara berjamaah atau sendiri (munfarid), ketika siswa berada di rumah sesuai dengan kondisi aktifitas salat yang sebenarnya, sebagai bahan acuan kami dalam memberikan arahan kepada siswa di sekolah. Pihak SDN 004 Cisaranten Kulon membagikan buku penghubung kepada semua siswa yang isinya berkenaan dengan absen salat lima waktu, baik itu dikerjakan secara berjamaah atau pun sendiri (munfarid). Sedangkan teknis yang dilakukan adalah bekerja sama dengan orang tua/wali siswa untuk ikut terlibat secara langsung dalam membina dan mendidik anaknya selama berada di rumah, apalagi pada masa pandemi ini anak-anak sepenuhnya belajar di rumah di bawah pengawasan orang tua. Tehniknya dengan bukti memberikan 
tanda tangan di buku penghubung tersebut dan secara berkala setiap 1 (satu) minggu menyerahkan buku penghubung tersebut kepada sekolah dan selanjutnya dievaluasi oleh pihak sekolah, dalam hal ini yaitu guru PAI kelas 5.

Komunikasi melalui zoom meeting orang tua/wali siswa yang disampaikan di grup whatsapp dilakukan di SDN 004 cisaranten Kulon melalui bantuan guru PAI sebagai usaha kerja sama antara guru PAI dan orang tua/wali di desain mulai dari undangan zoom, Kehadiran Perwakilan Orang Tua Murid dan Komite bisa mewakili untuk semua orang tua siswa kelas 5 yang berhalangan hadir di zoom meeting dan sudah tentu POM berkewajiban menyampaikan hasil dari Zoom tersebut.Berikut merupakan undangan zoom meeting.yang dilaksanakan oleh guru PAI dan orang tua siswa yang dilaksanakan sebagai bentuk Kerja sama antara Guru PAI dan Orang Tua dalam Meningkatkan Kedisiplinan salat siswa di SDN 004 Cisaranten Kulon.

Masa pandemi dengan waktu yang cukup panjang mengakibatkan tidak diperkenankan untuk mengadakan proses pembelajaran tatap muka di sekolah, tetapi Belajar Dari Rumah (BDR) atau dikenal juga Pembelajaran Jarak Jauh (PJJ) di SDN 004 Cisaranten Kulon tetap dilaksanakan. Begitu juga dengan laporan salat 5 waktu siswa, tetap dilaporkan setiap bulannya, dengan cara diwakili oleh ketua Persatuan Orang tua Murid dan Guru (POMG), dan komite sekolah yang sangat membantu untuk menyampaikan tugas kepada siswa secara luring atau luar jaringan.

Orang tua/wali siswa di rumah diharuskan membantu melengkapi buku ini ketika siswa berada di rumah sesuai dengan kondisi aktifitas salat yang sebenarnya, sebagai bahan acuan kami dalam memberikan arahan kepada siswa di sekolah. Selain itu, teknis yang dilakukan adalah siswa memberikan tanda contreng (V) atau tanda silang $(\mathrm{X})$ di dalam kolom yang telah tersedia di buku penghubung. Siswa memberikan tanda (V) apabila peserta didik melaksanakan salat 5 waktu baik secara berjamaah ataupun sendiri (munfarid), begitu pun sebaliknya peserta didik memberikan tanda silang (X) buku penghubung itu apabila siswa tidak melaksanakan salat 5 waktu. Program ini didukung dengan program-program lain, sebagai berikut: (1) Mengadakan pertemuan dengan orang tua pada hari penerimaan peserta didik baru, (2) Mengadakan surat menyurat antara sekolah atau guru PAI dengan pihak keluarga atau orang tua peserta didik. (3) Pembagian daftar nilai atau buku laporan semester. (4) Kunjungan wali kelas didampingi guru PAI ke rumah orang tua/wali siswa, atau sebaliknya kunjungan orang tua/wali siswa ke sekolah, (5) Mengadakan Peringatan Hari Besar Islam (PHBI), dan pembiasaan setiap hari Jum'at yaitu kegiatan salat Duha dan kultum bersama guru dan orang tua siswa, dan (6) Mendirikan perkumpulan orang tua peserta didik dan guru yang lebih dikenal POMG, dan komite sekolah.

Berdasarkan hasil rekapitulasi kedisiplinan salat lima waktu siswa kelas V di SDN 004 Cisaranten Kulon yang diteliti pada bulan Agustus dan September 2020. Pada bulan Agustus ini belum ada kerja sama antara guru PAI dan orang tua/wali. Melihat tabel rekapitulasi kedisiplinan salat siswa tersebut dapat diketahui bahwa pada bulan Agustus 2020, kedisiplinan salat lima waktu siswa SDN 004 Cisaranten Kulon menunjukkan presentase sebesar $73 \%$, sehingga hasil yang terlihat dari rekafitulasi tersebut secara mayoritas kedisiplinan salat siswa menunjukkan katagori Baik, dengan rincian sebagai berikut: jumlah keseluruhan 34 siswa yang mendapat katagori baik sekali ada 1 orang, katagori baik ada 32 orang dan katagori cukup 1 orang. Maka dari hasil rekapitulasi buku penghubung tersebut timbul program dilaksanakan kerja sama antara guru PAI dan orang tua siswa untuk melaksanakan kerja sama dalam meningkatkan kedisiplinan salat siswa Sedangkan hasil rekafitulasi kedisiplinan salat lima waktu siswa yang diteliti pada bulan September 2020 mengalami peningkatan sekitar 12,4\%, diketahui bahwa pada bulan ini, kedisiplinan salat lima waktu siswa SDN 004 Cisaranten Kulon menunjukkan presentase sebesar $85,4 \%$ sehingga secara mayoritas kedisiplinan salat siswa menunjukkan katagori Baik sekali, dengan rincian sebagai berikut: yang mendapat katagori baik sekali sebanyak 31 orang, dan yang mendapat katagori baik sebanyak 3 orang. Dari perbandingan tersebut sudah sangat terlihat program kerja sama antara guru Pai dan orang tua bisa membantu meningkatkan kedisipinan salat siswa di kelas 5 SDN 004 Cisaranten Kulon kecamatan Arcamanik kota Bandung. Kerja sama yang baik untuk keberhasilan suatu program yaitu meningkatkan kedisiplinan salat siswa.

2. Pelaksanaan Kerja Sama Antara Guru

PAI dan Orang Tua untuk Meningkatkan Kedisiplinan Siswa dalam Melaksanakan Salat Lima Waktu di Kelas V SDN 004 Cisaranten Kulon Kec. Arcamanik Kota Bandung

Pelaksanaan program ini, ada tahapantahapan yang dilakukan, berikut merupakan tahapan-tahapan yang kami lakukan: 
a.

Tahap wacana,

program kerja sama antara guru PAI dan orang tua untuk meningkatkan kedisiplinan siswa dalam melaksanakan salat lima waktu ini berawal dari pemikiran para guru khususnya guru PAI tentang rendahnya kedisiplinan salat siswa, terutama siswa kelas 4, 5 dan 6. Teramati bahwa sebagian siswa tersebut tidak melaksanakan salat ketika di sekolah (salat dzuhur atau salat asar). Padahal pihak sekolah sudah memberikan waktu istirahat untuk salat dan di sekolah pun sudah disiapkan mushalla selain itu sekolah pun dekat dengan mesjid Al-Falah yang cukup besar. Dalam pengamatan tersebut timbul pertanyaan dari benak guru-guru, jangan-jangan siswa bukan hanya tidak melaksanakan salat di sekolah saja, tetapi di rumah mereka pun tidak salat. Bagaimana sekarang siswa-siswi salatnya di rumah dikerjakan apa tidak di rumah. Pertanyaan-pertanyaan itu timbul, kemudian guru-guru PAI juga merespon dengan mewacanakan untuk membuat program kerja sama antara guru PAI dan orang tua untuk meningkatkan kedisiplinan siswa dalam melaksanakan salat lima waktu.

b. Tahap orientasi

pada tahap ini guru PAI SDN 004

Cisaranten Kulon melaporkan permasalahan yang terlihat kepada Kepala Sekolah sambil mengajukan proposal program kerja sama antara guru PAI kelas 5 dengan orang tua siswa yang telah diwacanakan. Kemudian Kepala Sekolah pun menerima laporan dan merespon dengan menyetujui program peningkatan kedisiplinan salat 5 waktu siswa dengan menggunakan Buku Penghubung Laporan Pelaksanaan Salat Lima Waktu Siswa yang diajukan oleh guru PAI. Kemudian Kepala Sekolah memberikan mandat sepenuhnya kepada guru PAI untuk pelaksanaan program dan ketua komite menyetujui program tersebut, dan mengirimkan pemberitahuan program kepada orang tua siswa, melalui ketua Persatuan Orang Tua dan Guru (POMG).

c. Tahap implementasi

pada tahap ini guru-guru PAI membuat dan menetapkan program-program peningkatan kedisiplinan salat 5 waktu siswa dengan menggunakan Buku Penghubung Laporan Pelaksanaan Salat Lima Waktu Siswa, kemudian mempublikasikannya kepada seluruh warga SDN 004 Cisaranten Kulon (guru, TU, penjaga sekolah, orang tua/wali siswa dan siswa). Kemudian untuk mendukung program peningkatan kedisiplinan salat 5 waktu siswa ini ada juga usaha-usaha lain yang dilakukan guru PAI kelas V SDN 004 Cisaranten Kulon, untuk mengintensifkan kerja sama dengan orang tua dalam pelaksanaan program peningkatan salat lima waktu siswa. Salah satunya diadakan zoom meeting dengan ketua Komite dan POMG

Kegiatan untuk mengintensifkan kerja sama dengan orang tua dalam pelaksanaan program peningkatan salat lima waktu siswa, yaitu

Mengadakan pertemuan dengan orang tua pada hari penerimaan peserta didik baru, serta membicarakan tentang perlunya kerja sama dalam mendidik anak-anaknya agar jangan sampai timbul salah paham, sambil juga mengadakan ceramah dari pemateri ahli, tentang pentingnya pembiasaan salat 5 waktu sejak dini, cara mendidik anak usia sekolah, dan lain sebagainya.

2) Mengadakan surat menyurat antara sekolah antara guru PAI dengan pihak keluarga atau orang tua peserta didik, terutama pada waktu- waktu yang sangat diperlukan bagi perbaikan pendidikan anak. Seperti surat peringatan dari guru PAI kepada orang tua jika anaknya perlu lebih giat dan disiplin dalam pelaksanaan salat 5 waktu.

3) Ketika pembagian daftar nilai atau buku laporan yang setiap semester dibagikan kepada peserta didik. Pada saat inilah kepala sekolah atau guru PAI mengingatkat atau meminta bantuan kepada orang tua peserta didik untuk memperhatikan peningkatan prestasi dan juga peningkatan kedisiplinan dalam pelaksanaan salat 5 waktu putra putrinya.

4) Kunjungan Orang tua/wali siswa ke sekolah atau sebaliknya kunjungan wali kelas didampingi guru PAI ke rumah orang tua/wali siswa. Hal ini lebih menguntungkan daripada hanya mengadakan surat menyurat saja. Kunjungan ini dilakukan apabila diperlukan, misalnya, untuk membicarakan kesulitan-kesulitan yang dialami di sekolah terhadap anak-anaknya atau mengunjungi peserta didik yang sembuh dan sakitnya untuk sekedar memberi hiburan. Umumnya, orang tua merasa senang atas kunjungan guru, karena ia merasa bahwa anaknya sangat diperhatikan oleh gurunya.

5) Mengadakan Peringatan Hari Besar Islam (PHBI), dan pembiasaan setiap hari Jum'at yaitu kegiatan salat Duha dan kultum, sebagai media untuk mengingatkan kembali orang tua/wali siswa, guru, dan siswa akan 
pentingnya pembiasaan ibadah khususnya salat 5 waktu.

6) Mendirikan perkumpulan orang tua/wali dan guru yang lebih dikenal POMG, dan komite sekolah. Dengan adanya wadah terebut, diharapkan dapat memberikan informasi kepada kedua belah pihak antara guru dengan orang tua/wali siswa tentang peningkatan kegiatan pembelajaran oleh peserta didik baik di sekolah maupun di rumah.

7) Selain itu, sekolah juga mengundang seluruh orang tua/wali siswa untuk mempublikasikan program ini serta menyerahkan buku penghubung salat 5 waktu. Selain itu guru PAI juga menyiapkan buku rekap, untuk mengevaluasi perkembangan kedisiplinan siswa dalam salat 5 waktu. Kemudian dari hasil evaluasi tersebut dilakukan tindakantindakan antisipatif dan responsive merupakan tindakan yang dilakukan setelah terjadi perbuatan yang melanggar, tindakan ini berfungsi untuk memperbaiki perbuatan pelanggaran tersebut.

\section{d. Tahap evaluasi}

Tahap perencanaan dan pelaksanaan program telah dilaksanakan maka sampai pada tahap evaluasi, pada tahap ini guru PAI SDN 004 Cisaranten Kulon melakukan pengamatan dan penilaian dari program yang sudah dijalankan dengan mengkaji laporan dari orang tua melalui buku penghubung salat 5 waktu, disiplin siswa melaksanakan salat lima waktu baik yang dilaksanakan secara munfarid atau berjamaah.

\section{Keberhasilan Pelaksanaan Kerja Sama} Antara Guru PAI dan Orang Tua untuk Meningkatkan Kedisiplinan Siswa dalam Melaksanakan Salat Lima Waktu di Kelas V SDN 004 Cisaranten Kulon Kec. Arcamanik Kota Bandung

Setelah dilaksanakannya program kedisiplinan Salat Lima Waktu siswa di kelas V SDN 004 Cisaranten Kulon pada bulan Agustus dan September 2020, pada bulan September 2020 terdapat kenaikan sebesar $12,4 \%$, yaitu dari $73 \%$ di bulan Agustus, menjadi $85.4 \%$ pada bulan September.

Kerja sama antara guru PAI dan orang tua yang dilaksanakan untuk meningkatkan kedisiplinan salat siswa di SDN 004 Cisaranten
Kulon berdampak positif, terutama pada keberhasilan program. Hal ini dapat diamati:

a. Dukungan sarana dan prasarana, baik dari sekoalah maupun orang tua/wali siswa yang diberikan melalui komite sekolah.

b. Banyaknya siswa yang melakukan salat fardu di mushala atau mesjid dari hari ke hari semakin bertambah, hal tersebut menandakan bahwa sudah adanya kesadaran dari diri siswa untuk melaksanakan salat 5 waktu sebagai kewajiban

c. Tumbuhnya kesadaran siswa untuk belajar melaksanakan salat, dan bacaan salat mereka yang sudah benar.

d. Siswa mengerjakan salat tepat pada waktunya ketika berada di rumah, berdampak juga pada belajar mengaji, menjadi lebih giat dan hapalan surat-surat pendek lebih baik serta membaca al-Qur'an lebih lancar.

4. Faktor Pendukung dan Penghambat Pelaksanaan Kerja Sama Antara Guru PAI dan Orang Tua untuk Meningkatkan Kedisiplinan Siswa dalam Melaksanakan Salat Lima Waktu di Kelas V SDN 004 Cisaranten Kulon Kec. Arcamanik Kota Bandung

Dari hasil wawancara didapat adanya faktor pendukung dan penghambat ini pada faktor internal dan eksternal. Faktor-faktor tersebut yaitu:

a. Faktor Internal Sekolah yang menjadi Pendukung Pelaksanaan Kerja Sama Antara Guru PAI dan Orang Tua untuk Meningkatkan Kedisiplinan Siswa dalam Melaksanakan Salat Lima Waktu Di Kelas V SDN 004 Cisaranten Kulon Kec. Arcamanik Kota Bandung. Diantara faktor internal sekolah yang menjadi pendukung program ini yaitu :

1) Mayoritas siswa di SDN 004 Cisaranten Kulon,merupakan muslim, sehingga memudahkan pencapaian program-program keagamaan.

2) Kerja sama antara pihak komite sekolah dan orang tua/wali siswa yang berjalan secara baik, orang tua sering memberikan bantuan kepada sekolah untuk kelancaran program kerja sama antara guru PAI dan orang tua untuk meningkatkan kedisiplinan siswa dalam 
melaksanakan salat 5 waktu ini yang dikumpulkan melalui komite, diantaranya membantu sebagian dana untuk membangun mushala, sarana air wudhu, pengadaan alQur'an dan alat salat.

3) Sekolah sudah memfasilitasi ketersediaan mushala dan sarana pendukung lainnya untuk dioptimalkan dalam program kerjasama antara guru PAI dan orang tua untuk meningkatkan kedisiplinan siswa dalam melaksanakan salat lima waktu.

4) Semua guru PAI di SDN 004 Cisaranten Kulon sudah menempuh pendidikan S1 dan sudah disertifikasi, dengan pendidikan miniml S1 harus mampu mengantarkan manusia untuk mencapai keberhasilan hidup baik kehidupan duniawi atau ukhrawi, sehinga secara tidak langsung turut mendukung kelancaran pelaksanaan program ini, diantaranya melalui ide-ide dan inovasi-inovasi pembelajaran yang mengarah pada dukungan terhadap program ini, seperti menyisipkan penjelasanpenjelasan tentang pentingnya salat 5 waktu dalam setiap pembelajaran di kelas.

b. Faktor Eksternal Sekolah yang menjadi Pendukung Pelaksanaan Kerja Sama Antara Guru PAI dan Orang Tua untuk Meningkatkan Kedisiplinan Siswa dalam Melaksanakan Salat Lima Waktu Di Kelas V SDN 004 Cisaranten Kulon Kec. Arcamanik Kota Bandung.

Diantara faktor eksternal sekolah yang menjadi pendukung program ini, yaitu:

1) Visi Kota Bandung,yaitu:

Terwujudnya kota Bandung yang unggul nyaman, sejahtera dan agamis. Kesejahteraan dalam artinya yang sejati adalah keseimbangan hidup yang merupakan buah dari kemampuan seseorang untuk memenuhi tuntutan dasar seluruh dimensi dirinya, meliputi ruhani, akal dan jasad.

2) SDN 004 Cisaranten Kulon dikelilingi oleh masyarakat yang mayoritas beragama Islam, pendidikan agama yang sangat dibutuhkan dalam proses pemberdayaan manusia menuju kedewasaan, adanya masjid yang cukup besar disekitar Cisaranten Kulon, sehingga secara tidak langsung turut mendukung program peningkatan kedisiplinan salat 5 waktu siswa, banyak siswa yang memanfaatkan masjid tersebut.

3) Orang tua yang mendaftarkan putraputrinya ke SDN 004 Cisaranten Kulon ini banyak diantaranya merupakan orang tua yang memiliki komitmen tinggi terhadap pendidikan agama, sehingga terwujud kerja sama yang kooperatif antara orang tua dan guru PAI dalam upaya mencetak anak yang saleh, dengan kata lain pembiasaan ibadah dan akhlak mulia di sekolah didorong oleh orang tua untuk dibiasakan juga di rumah. Hal ini dapat teramati dari banyaknya siswa yang mengaji dengan berbagai cara,yaitu:

a) Siswa yang mengaji ke TPA/DTA Al-Falah

b) Siswa yang mengaji di masjidmasjid yang terdekat dengan tempat tinggal mereka

c) Siswa yang mengaji ke rumah guru.

d) Siswa yang mengaji di rumahnya dengan diajari oleh orang tuanya.

e) Siswa yang memanggil guru privat mengaji ke rumahnya.

4) Dukungan dan kerja sama aktif orang tua/wali siswa kepada sekolah dalam monitoring salat 5 waktu di rumah, dengan mengisi buku penghubung yang telah disediakan guru PAI.

5) Dukungan pemerintah dalam pengadaan sarana dan prasarana pembelajaran keagamaan (PAI).

c. Faktor Internal Sekolah yang menjadi Penghambat Pelaksanaan Kerja Sama Antara Guru PAI dan Orang Tua untuk Meningkatan Kedisiplinan Siswa dalam Melaksanakan Salat Lima Waktu Di Kelas V SDN 004 Cisaranten Kulon Kec. Arcamanik Kota Bandung. Diantara faktor internal sekolah yang menjadi penghambat program ini, yaitu :

1) Masih terbatasnya fasilitas, terutama alat salat (mukena dan sarung), sehingga siswa harus lama mengantri karena bergantian untuk memakai mukena dan sarung dengan siswa lainnya

2) Masih adanya beberapa orang tua/wali siswa yang terkadang lupa mengisi buku penghubung salat 5 waktu dan mengingatkan putra putrinya untuk salat lima waktu di rumah, terutama disaat liburan. Adanya pembagian wewenang dan tanggung jawab dalam tugas, 
peluang untuk saling bekerja sama antara guru dan orang tua/wali siswa, termasuk salah satunya mengisi buku penghubung.

d. Faktor Eksternal Sekolah yang menjadi Penghambat Pelaksanaan Kerja Sama Antara Guru PAI dan Orang Tua untuk Meningkatan Kedisiplinan Siswa dalam Melaksanakan Salat Lima Waktu Di Kelas V SDN 004 Cisaranten Kulon Kec. Arcamanik Kota Bandung. Diantara faktor eksternal sekolah yang menjadi penghambat program ini, yaitu:

1) Adanya latar belakang pendidikan sebagian orang tua yang rendah sehingga mereka kurang memberikan perhatian terhadap pendidikan agama di sekolah, orang tua yang tidak memberi teladan yang baik dalam pelaksanaan salat lima waktu mereka cenderung memasrahkan secara penuh pendidikan agama kepada guru agama dan tempat mengaji. sehingga kurang terwujudnya kerja sama yang kooperatif antara orang tua dan guru PAI di sekolah dalam upaya mencetak anak yang saleh, terutaama mendisiplinkan salat lima waktu siswa.

2) Latar belakang lingkungan tempat tinggal dan tempat bergaul siswa yang memungkinkan menyeret siswa pada lingkungan dan kebiasaan negatif, seperti terus bermain tidak mau berhenti bersama temaantemannya di saat adzan sudah berkumandang, kebiasaan bermain handphon (game online).

Namun dari beberapa faktor penghambat ini relatif tidak terlau banyak, dan masih bisa diatasi sehingga banyak siswa masih dapat diarahkan diberi wejangan, dan dipengaruhi oleh guru, orang tua, guru mengaji dan kawan-kawannya sehingga tidak terjerumus pada pergaulan negatif yang dapat menjadikan mereka menjadi malas dan tidak disiplin dalam melaksanakan salat 5 waktu.

\section{E. SIMPULAN DAN SARAN}

Penulis dapat menarik beberapa kesimpulan yang mengacu pada rumusan masaalah penelitian.

1. Desain peningkatan kedisiplinan siswa dalam melaksanakan salat lima waktu melalui kerja sama antara guru PAI dan orang tua siswa, yaitu pertama dengan adanya program pertemuan yang dilaksanakan minimal waktu tiga bulan sekali dan maksimal waktu seminggu sekali. Kedua dengan menggunakan buku penghubung yang dinamai "Buku Penghubung Laporan Pelaksanaan Salat Lima Waktu". Buku penghubung ini sabagai salah satu bentuk kerja sama antara sekolah dan orang tua siswa dalam meningkatkan ibadah salat siswa baik di rumah maupun di sekolah.

2. Dalam pelaksanaan program ini ada tahapan-tahapan yang dilakukan, berikut merupakan tahapan-tahapan yang kami lakukan: a) Tahap wacana, tahap ini Guru PAI mewacanakan untuk membuat program kerja sama antara guru PAI dan orang tua untuk meningkatkan kedisiplinan siswa dalam melaksanakan salat lima waktu.; b) Tahap orientasi, pada tahap ini guru PAI melaporkan permasalahan yang terlihat kepada Kepala Sekolah sambil mengajukan proposal program kerja sama yang telah diwacanakan, Kemudian Kepala Sekolah dan menyetujui program ini.; c) Tahap implementasi, pada tahap ini guru PAI membuat dan menetapkan program serta mempublikasikannya kepada seluruh warga sekolah (guru, TU, penjaga sekolah, orang tua/wali siswa dan siswa). Selain itu, sekolah juga mengundang seluruh orang tua/wali siswa untuk mempublikasikan program ini serta menyerahkan serta menyerahkan buku penghubung salat 5 waktu; dan d) tahap evaluasi, pada tahap ini guru PAI melakukan pengamatan dan penilaian program, dilakukan baik terhadap perilaku kedisiplinan siswa dalam pelaksanaan salat 5 waktu, maupun terhadap programnya itu sendiri. Setelah diketahui hasilnya, maka guru PAI akan melakukan perbaikan baik terhadap siswa, maupun pogramnya.

3. Keberhasilan Pelaksanaan Kerja Sama antara Guru PAI dan Orang Tua untuk Meningkatkan Kedisiplinan Siswa dalam Melaksanakan Salat Lima Waktu, yaitu Setelah dilaksanakannya program kedisiplinan Salat Lima Waktu siswa pada bulan Agustus dan September 2020, pada bulan September 2020 terdapat kenaikan dengan terlihatnya banyaknya siswa yang salat berjamaah di lingkungan tempat tinggal. 
4. Faktor Pendukung dan Penghambat Pelaksanaan Kerja Sama Antara Guru PAI dan Orang Tua untuk Meningkatkan Kedisiplinan Siswa dalam Melaksanakan Salat Lima Waktu, yaitu:

a. Faktor Pendukung

1) Kerja sama antara pihak komite sekolah dan orang tua/wali siswa yang berjalan secara baik, orang tua sering memberikan bantuan kepada sekolah untuk kelancaran program kerja sama antara guru PAI dan orang tua untuk meningkatkan kedisiplinan siswa dalam melaksanakan salat 5 waktu.

2) Sekolah sudah memfasilitasi ketersediaan mushala dan sarana pendukung lainnya untuk meningkatkan kedisiplinan siswa dalam melaksanakan salat lima waktu.

3) Semua guru PAI di SDN 004 Cisaranten Kulon sudah menempuh pendidikan S1 dan sudah disertifikasi, sehinga secara tidak langsung turut mendukung kelancaran pelaksanaan program ini.

4) Visi Kota Bandung,yaitu:

Terwujudnya Kota Bandung Yang Unggul Nyaman, Sejahtera dan Agamis. Sejahtera dalam artinya yang sejati adalah keseimbangan hidup yang merupakan buah dari kemampuan seseorang untuk memenuhi tuntutan dasar seluruh dimensi dirinya, meliputi ruhani, akal dan jasad.

5) Orang tua yang mendaftarkan putraputrinya ke SDN 004 Cisaranten Kulon ini banyak diantaranya merupakan orang tua yang memiliki komitmen tinggi terhadap pendidikan agama, sehingga terwujud kerja sama yang kooperatif antara orang tua dan guru Pendidikan Agama Islam (PAI) dalam upaya mencetak anak yang saleh, dengan kata lain pembiasaan ibadah.

6) Dukungan dan kerja sama aktif orang tua/wali siswa kepada sekolah dalam monitoring salat 5 waktu di rumah, dengan mengisi buku penghubung yang telah disediakan guru Pendidikan Agama Islam (PAI).

7) Dukungan pemerintah dalam pengadaan sarana dan prasarana pembelajaran Pendidikan Agama Islam (PAI).

b. Faktor Penghambat

1) Masih terbatasnya fasilitas, terutama alat salat (mukena dan sarung), sehingga siswa harus lama mengantri karena bergantian untuk memakai mukena dan sarung dengan siswa lainnya

2) Masih adanya beberapa orang tua/wali siswa yang terkadang lupa mengisi buku penghubung salat 5 waktu dan mengingatkan putra putrinya untuk salat lima waktu di rumah, terutama disaat liburan.

3) Adanya latar belakang pendidikan sebagian orang tua yang rendah sehingga mereka kurang memberikan perhatian terhadap pendidikan agama di sekolah, mereka cenderung memasrahkan secara penuh pendidikan agama kepada guru agama dan tempat mengaji saja, sehingga kurang terwujudnya kerja sama.

4) Latar belakang lingkungan tempat tinggal dan tempat bergaul siswa yang memungkinkan menyeret siswa pada lingkungan dan kebiasaan negatif, seperti kebiasaan bermain handphone (game online).

Berdasarkan kesimpulan di atas ada beberapa saran bagi beberapa pihak sebagai berikut:

1. Bagi Pemerintah Kota Bandung

Berhubung jam belajar agama di sekolah masih terbatas, maka demi untuk menanamkan ajaran agama Islam kepada generasi muda maka pemerintah Kota Bandung diharapkan dapat meningkatkan perhatiannya pada pendidikan keagamaan, dengan segera mengesahkan Peraturan Daerah tentang wajib belajar Diniyah Takmiliyah Awwaliyah (DTA) bagi siswa SD.

2. Bagi Pihak Sekolah

a. Hasil Penelitian ini dapat dipergunakan sebagai bahan kajian daalam pengembangan pembelajaran Agama Islam agar lebih baik lagi. 
b. Penerapan program Kerja sama Antara Guru PAI dan Orang Tua untuk Meningkatkan Kedisiplinan Siswa dalam Melaksanakan Salat Lima Waktu Di Kelas V SDN 004 Cisaranten Kulon Kec. Arcamanik Kota Bandung, selama ini telah berjalan dengan baik, hendaknya dipertahankan dan ditingkatkan secara lebih intensif, terutama dalam memotivasi siswa agar memiliki kesadaran yang tinggi untuk memahami dan mengamalkan ajaranajaran agama Islam. Jika memungkinkan dapat dikembangkan dengan ditambah pembiasaan lainnya, seperti: membaca Al Qur'an (tadarus/tilawah), hapalan (tahfizh) juz 'amma, sedekah, ibadah-ibadah sunah (salat dan shaum sunah).

c. Mengoptimalkan kegiatan ekstrakurikuler ke PAI-an yang lebih variatif sehingga para siswa dapat terpenuhi keinginannya untuk mengapresiasikan bakat dan minatnya dalam bidang agama, seperti menyelenggarakan ekstrakurikuler qiro'at, kesenian Islam (nasyid/qasidah/marawis), bimbingan dakwah/ceramah (dacil), dan lain sebagainya.

d. Hendaknya meningkatkan kerja sama dan diskusi dengan orang tua tentang bagaimana menanamkan nilai-nilai agama Islam dalam kehidupan seharihari atau jika diperlukan dapat mengadakan pelatihan untuk membina anak saleh, kerena kegiatan ini sangat diperlukan agar kerja sama dengan pihak orang tua bisa terjalin lebih baik, karena waktu siswa lebih banyak di luar sekolah atau di rumah apalagi pada saat pandemi sekarang ini, sehingga para orang tua diharapkan mampu untuk membantu para guru baik untuk memotivasi, mengarahkan atau memberi contoh teladan yang berkaitan dengan agama Islam di rumah.

e. Hendaknya pihak sekolah memfasilitasi guru-guru PAI untuk melakukan studi banding ke SD lain yang sudah lebih baik dalam pengelolaan kegiatan keagamaannya, sehingga dapat menambah wawasan dansebagai perbandingan guru PAI dalam mengelola aktifitas pembelajaran PAI di tempat dimana mereka bekerja dan mengamalkan semua hasil temuannya dari tempat studi banding yang telah di kunjunginya.

3. Bagi Guru

a. Guru PAI bekerja sama dengan wali kelas agar lebih mengintensifkan program home visit, supaya dapat langsung memantau kegiatan siswa di rumahnya masing-masing.

b. Untuk lebih meningkatkan prestasi dan pengamalan siswa dalam mata pelajaran PAI, maka siswa tersebut harus diwajibkan oleh guru-guru PAI dan wali kelasnya untuk mengikuti pengajian di mesjid di lingkungan tempat tinggal sekitarnya, dengan dibuktikan oleh surat keterangan/raport dari DTA yang ditunjukkan kepada guru PAI dan wali kelasnya dalam setiap semesternya.

c. Untuk memotivasi siswa, guru PAI atau wali kelas dapat memberikan hadiah atau penghargaan bagi siswa yang paling rajin salat 5 waktu, terutama bagi siswa yang mengerjakannya berjamaah.

d. Semua guru dihimbau juga agar bersama sama mendukung program ini, dengan memberikan motivasi kepada siswa akan pentingnya salat 5 waktu dan menyesuaikan jadwal dengan waktu salat, jangan sampai siswa melaksanakan salatnya terlalu jauh dari awal waktu salat atau jangan sampai siswa melaksanakan salat di akhir waktu.

4. Bagi Peneliti selanjutnya

a. Bagi peneliti yang hendak melakukan penelitian selanjutnya disarankan memperhatikan faktor-faktor penghaambat pada penelitian yang dijelaskan pada bab IV, sebagai bahan pertimbaangan demi tercapainya tujuan penelitian

b. Perlu ada penelitian lebih lanjut mengenai kerja sama antara guru PAI dan orang tua untuk diterapkan pada indikator kedisiplinaan yang lainnya, karena pada kesempatan kali ini peneliti haanya melaksanakan penelitian mengenai kedissiplinan salat siswa.

\section{F. DAFTAR PUSTAKA}


Abdurrahman, M. 2010. Pendidikan bagi Anak Berkesulitan Belajar, Jakarta: Rineka Cipta. hlm 106

Al Albani, M. N. 2006. Shahih Sunan Tirmidzi Buku I. Jakarta: Pustaka Azzam.

Arikunto, S. 2010. Prosedur Penelitian: Suatu Pendekatan Praktek. Jakarta: Rineka Cipta.

Arikunto, Suharsimi. 2014. Prosedur Penelitian: Suatu Pendekatan Praktik. Jakarta: Rineka Cipta.

Daulay, H. P. 2012. Pendidikan Islam Dalam Mencerdaskan Bangsa. Jakarta: Bhineka Cipta.

Daradjat, Z. 1996. Pendidikan Islam dalam Keluarga dan Sekolah. Jakarta: Ruhama.

Depag RI. 2004. Pedoman Integrasi Life Skills dalam Pembelajaran Madrasah Aliyah. Jakarta: Direktorat Jenderal Kelembagaan Agama Islam

Dimyati dan Mudjiono. 2006. Belajar dan Pembelajaran. Jakarta: Rineka Cipta).

Edwards.D. 2006. Flow to handle a Hand to Handle Kit a Parents' Guide to Understanding and Changing Problem Behaviors. Terj. Oetih F.D> ketika Anak Sulit Diatur: Panduan bagi Pars Orang Tua Untuk Mengubah Masalah Perilaku Anak. Bandung: Mizan Pustaka

Fathoni, A. 2006. Manajemen Sumber Daya Manusia. Jakarta: Rineka Cipta

Harjaningrum, A. T., dkk. 2007. Peranan Orang Tua dan Praktisi dalam Membantu Tumbuh Kembang anak Berbakat Melalui Pemahaman Teori dan Tren. Jakarta: Prenada Media Grup.

Helmawati. 2015 Sistem Informasi Manajemen Pendidikan Agama Islam.Hal 61. Bandung: Remaja Rosdakarya

Kementerian Pendidikan dan Kebudayaan. 2012. Pengembangan Kurikulum 2013.

Lexy J. Meleong. 2007. Metode Penelitian Kualitatif. Bandung: Remaja Rosdakarya.
Mahmud. 2011. Metode Penelitian Pendidikan. Bandung Pustaka Setia.

Majid, A. dan Andayani, D. 2005. Pendidikan Agama Islam Berbasis Kompetensi: Konsep dan Implementasi Kurikulum 2004. Remaja Rosdakarya: Bandung

Mudyhardjo, R. 2001. Pengantar Pendidikan. Jakarta Radja Grafindo Persada.

Muhaimin. 2012. Paradigma Pendidikan Islam: Upaya Mengefektifkan Pendidikan agama Islam di Sekolah. Remaja Rosdakarya: Bandung.

Mulyasa, E. 2017 Revolusi Mental Dalam Pendidikan.hal 117 Bandung: Remaja Rosdakarya

2017 Menjadi Guru Profesional.hal

170 Bandung: Remaja Rosdakarya

2019 Implementasi Kurikulum 2013 Revisi hal 29. Jakarta: Bumi Aksara

Musyfiqon. 2012 Panduan Lengkap Metodologi Penelitian. Jakarta: Prestasi Pustakarya.

Permendikbud No. 81-A Tahun 2013 tentang Implementasi Kurikulum 2013: Remaja Rosda Karya

Purwanto, N. 1988. Ilmu Pendidikan Teoritis dan Praktis. Bandung: Remaja Rosdakarya

Rahim, A. M. 2002. Tarbiyyah Menjawab Tantangan. Jakarta Rabbani Press

Sanjaya, W. 2010. Kurikulum dan Pembelajaran: Teori dan Praktik Pengembangan Kurikulum Tingkat Satuan Pendidikan (KTSP). Kencana Prenada Media Grup: Jakarta.

Shihab. M. Q. 2002. Tafsir Al- Mishbah Pesan, Kesan dan Keserasian Al-Qur'an Volume I. Jakarta: Lentera Hati

Shochib. M. 1998. Pola Asuh Orang tua. Jakarta: Rineka Cipta.

Soekanto, S. 1986. Sosiologi Kerja sama. Jakarta: Media Utama.

Sugiyono. 2012. Memahami Penelitian Kualitatif. Bandung: Alfabeta 
Syaamil quran Al-Qur'an Fadhilah Terjemah \& Transliterasi Latin Sygma 2011 hal 281

Syah, Muhibbin. 2016. Psikologi Pendidikan dengan Pendekatan Baru. Bandung:

Syaltut, Mahmud. 1994. Aqidah dan Syariah Islam. Jakarta: Bumi Aksara.

Tafsir, A. 2016. Ilmu Pendidikan dalam Persefektif Islam. Bandung: Rosdakarya

. 2016. Metodologi Pengajaran Agama Islam. Bandung: Rosdakarya

. 2017 Filsafat pendidikan Islam hal 171 Bandung: Remaja RosdakaryA

Tim Penyusun Kamus Pusat Bahasa. 2008. Kamus Bahasa Indonesia. Pusat Bahasa: Jakarta. (Pdf)

Yaya Suryana dan Tedi Priatna. 2007. Metode Penelitian Pendidikan. Bandung Azkia Putra Utama.

Zuhri, M. 1982. Kelengkapan Hadits Qudsi. Semarang: Toha Putra. 